\title{
SPATIAL DIFFERENCES IN THE NUMBER OF APPLICATIONS FOR PAYMENTS UNDER THE EU COMMON AGRICULTURAL POLICY SUBMITTED BY AGRICULTURAL HOLDINGS IN POLAND OVER THE YEARS 2002-2010
}

\author{
ROMAN RUDNICKI \\ Chair of Spatial Management and Tourism, Nicolaus Copernicus University, Torun, Poland \\ Manuscript received: January 5, 2013 \\ Revised version: January 18, 2013
}

\begin{abstract}
RUDNICKI R., 2013. Spatial differences in the number of applications for payments under the EU Common Agricultural Policy submitted by agricultural holdings in Poland over the years 2002-2010. Quaestiones Geographicae 32(4), Bogucki Wydawnictwo Naukowe, Poznań, pp. 15-31, 7 figs, 7 tables. DOI 10.2478/quageo-2013-0030, ISSN 0137-477X.

ABstRAct. This article offers a spatial analysis of the number of applications submitted by agricultural holdings in Poland for funds under the European Union's Common Agricultural Policy over the years 2002-2010 (a total of 874 thous. applications, Table 1). This activity was characterised by dividing the assistance means obtained into measures intended to improve: the natural environment (Table 2, Fig. 1), the agrarian-demographic structure (Table 3, Fig. 2), the technical equipment of farms (Table 4, Fig. 3), and their income situation (Table 5, Fig. 4). The above measures are also shown jointly (Table 6, Fig. 5) and spatial differences in their structure are presented (Table 7, Figs 6 and 7). The analysis showed there to be wide territorial differences among agricultural holdings in Poland in terms of the total number and structure of the CAP measures they implemented.
\end{abstract}

KEY WORDS: Common Agricultural Policy, financial support for agricultural holdings, agricultural holdings, agriculture, history, Poland

Roman Rudnicki, Chair of Spatial Management and Tourism, Faculty of Earth Sciences, Nicolaus Copernicus University, ul. Lwowska 1,87-100 Toruń, Poland; e-mail: rrudnicki@umk.pl

\section{Introduction}

Poland's membership of the European Union has given the country a good chance for development as manifested by both, several improved socio-economic indices and the levelling out of spatial disproportions among them. This is an especially important issue in the case of agriculture, which, on the one hand, is due to its low general level and wide differences in its spatial structure caused by natural, historical and urbanisation-related factors (cf. Bański 2007, Głębocki 2007), and on the other hand, to the fact that agricultural holdings have become beneficiaries of a wide array of Common Agricultural Policy (CAP) instruments (cf. Rudnicki 2010).

This article seeks to assess spatial differences in EU assistance for agriculture, especially as seen in terms of the Community's cohesion policy. It thus contributes to a wider academic discussion on this subject (e.g. Drygas, Rosner 2008, Kołodziejczak 2006, Shucksmith et al., Trouve 2006).

To assess the influence of the EU funds on farming, a study was made concerning the number of applications submitted by Polish agricultural holdings over the years 2002-2010 for financial 
support under the various EU programmes. The analysis, based on several operational CAP programmes intended to implement concrete modernisation measures, embraced the years 20022004 and their Special Accession Programme for Agriculture and Rural Development (SAPARD; cf. Rudnicki 2008), the first financial period of Poland's EU membership (the years 2004-2006) and its two instruments, the Rural Development Plan (RDP; cf. Plan Rozwoju ... 2004) and the Sectoral Operational Programme "Restructuring and Modernisation of the Food Sector and Rural Development" (SOP_Agri; cf. Sektorowy Program Operacyjny ... 2004), as well as measures currently - as of the end of 2010 - implemented under the Rural Development Programme 2007-2013 (RDP; cf. Program Rozwoju ... 2007). Ignored in the analysis were area payments, Support for agricultural activity in less-favoured areas (LFAs, under the RDP), which is similar to them, and RDP 2007-2013 measures launched at a wider scale only after 2010, viz. Restoring agricultural production potential, Use by farmers of advisory ser- vices, and Participation of farmers in food quality schemes. Because of difficulties with spatial analysis, support for groups of agricultural producers was not taken into account either.

In sum, the analysis embraced ten CAP assistance measures. They were divided into four groups: the improvement of the natural environment, of the agrarian-demographic structure, of the technical equipment of farms, and of their income situation (cf. Table 1). It should be stressed that under those measures the farmer had to prepare an application for a subsidy (often with the help of an advisory firm) justifying the rationality of the planned venture and presenting a schedule of steps to be taken (a business plan); and his way of spending the funds obtained was controlled from outside.

In the article use is made of the data of the Agency for Restructuring and Modernisation of Agriculture (AR\&MA), with its 314 poviat offices adopted as basic units of spatial analysis (for the description of the AR\&MA's organisational division into regional branches and poviat of-

Table 1. Number of applications under CAP assistance programmes submitted by agricultural holdings in Poland over the years 2002-2010.

\begin{tabular}{|c|c|c|c|c|c|}
\hline \multirow{2}{*}{ Programmes - measures } & \multicolumn{3}{|c|}{ Years } & \multicolumn{2}{c|}{$2002-2010$} \\
\cline { 2 - 6 } & \multicolumn{3}{|c|}{ in thous. applications } \\
\cline { 2 - 6 } & $\begin{array}{c}\text { 2002-2004 } \\
\text { (SAPARD) }\end{array}$ & $\begin{array}{c}\text { 2004-2006 } \\
\text { (RDP, } \\
\text { SOP_agri) }\end{array}$ & $\begin{array}{c}\text { 2007- } \\
\text { 2010 }\end{array}$ & RDP) & total \\
\hline Improvement of the natural environment, of which & - & 355.7 & 114.2 & 469.9 & 53.8 \\
\hline Agri-environmental programme & - & 308.7 & 97.2 & 405.9 & 46.5 \\
\hline Land afforestation & - & 47.0 & 17.0 & 64.0 & 7.3 \\
\hline $\begin{array}{l}\text { Improvement of agrarian-demographic structure, } \\
\text { of which }\end{array}$ & - & 68.2 & 29.7 & 97.9 & 11.2 \\
\hline Structural pensions & - & 54.0 & 13.7 & 67.7 & 7.7 \\
\hline Setting-up of young farmers & - & 14.2 & 16.0 & 30.2 & 3.5 \\
\hline $\begin{array}{l}\text { Improvement of technical equipment of farms, } \\
\text { of which }\end{array}$ & 12.9 & 97.6 & 29.1 & 139.6 & 16.0 \\
\hline Investment on agricultural holdings & 12.9 & 24.5 & - & 37.4 & 4.3 \\
\hline Adjustment of agricultural holdings to EU standards & - & 69.7 & - & 69.7 & 8.0 \\
\hline $\begin{array}{l}\text { Development and improvement of farming-related } \\
\text { physical infrastructure }\end{array}$ & - & 3.4 & - & 3.4 & 0.4 \\
\hline Modernisation of agricultural holdings & - & - & 29.1 & 29.1 & 3.3 \\
\hline Improvement of income situation, of which & 1.5 & 161.8 & 3.1 & 166.3 & 19.0 \\
\hline Support for semi-subsistence farms & - & 157.7 & - & 157.7 & 18.0 \\
\hline Diversification into non-agricultural activities & 1.5 & 4.1 & 3.1 & 8.6 & 1.0 \\
\hline Number of applications granted - total & 683.3 & 176.1 & 873.8 & 100.0 \\
\hline
\end{tabular}

Source: own compilation on the basis of data of the Agency for Restructuring and Modernisation of Agriculture (AR\&MA). 
fices, see Rudnicki 2009: 6-8). The basis of the analysis was an index of activity defined as the proportion of farms involved in the given CAP measure (or group of measures) in the total number of agricultural holdings engaged in farming on more than 1 ha agricultural land $(14,484,000$ farms according to the 2010 Agricultural Census, cf. the Local Data Bank of GUS, the Central Statistical Office).

To make a fuller assessment of the spatial patterns obtained, the level and structure of the activity of agricultural holdings in absorbing EU funds were compared against differences in their natural and extra-natural conditions. Under the former heading, on the basis of the index of the quality of agricultural production space (QAPS) and the criteria of eligibility for the RDP measure Support for agricultural activity in less-favoured areas (LFAs), regions were distinguished with unfavourable conditions (under 52 QAPS points; lowland zone), moderately favourable (52-72 QAPS points; lowland zone), and favourable ones (QAPS over 72; ineligible for LFA payments). Under the heading of extra-natural conditions, two determinants were distinguished:

- historical - poviats situated (1) in the former Austrian sector and within the boundaries of interwar Poland, (2) in the former Prussian sector and within the boundaries of interwar Poland, (3) in the former Russian sector and within the boundaries of interwar Poland, and (4) in the former Prussian sector and within the boundaries of interwar Germany; and

- urbanisation-related - poviats classed as (1) poorly urbanised (situated in predominantly rural sub-regions), (2) moderately urbanised (situated in intermediate sub-regions), and (3) highly urbanised (situated in predominantly urban sub-regions; the division after the GUS Local Data Bank).

\section{CAP measures intended to improve the natural environment}

Two of the CAP instruments analysed were designed for an improvement of the natural environment, viz.:

1. Agri-environmental payments; amounting to 3,683 million zlotys, they were intend- ed to encourage farmers to introduce environment-friendly production methods. This measure was implemented under RDP 2004-2006 as Support for agri-environmental ventures and improvement of animal welfare (payments being granted in the form of seven packages embracing the entire country or selected priority zones), and under RDP 20072013 as The agri-environmental programme (in the form of nine packages embracing the entire country). One holding could apply for assistance under up to three packages, which resulted in a record number of applications (405.9 thous.).

2. Land afforestation; the measure was intended to help extend forest resources on land used by agricultural holdings. It was implemented under RDP 2004-2006 (Afforestation of agricultural land of low farming use) and RDP 2007-2013 (when the measure was extended to the afforestation of land other than agricultural). In all, there were 15.3 thous. applications and payments to the amount of 734 million zlotys.

In sum, over the study period agricultural holdings submitted 469.9 thous. applications involving an improvement of the natural environment. In this group the programme enjoying the greater popularity among farmers was the agri-environmental one, accounting for an average of $86.4 \%$ of applications (from $71.5 \%$ in Warmia-Mazuria to $93.4 \%$ in West Pomerania), and in the years 2004-2006, for an average of $75.7 \%$ of applications (from $67.9 \%$ in Kujavia-Pomerania to $87.0 \%$ in Opole; cf. Table 2).

Over the study period, the average index of activity of agricultural holdings under pro-environmental CAP measures amounted to $31.7 \%$. This proportion showed wide spatial differences, both by voivodeship (from $13.2 \%$ in Silesia to 76.5 in West Pomerania; cf. Table 2 ) and by poviat (from $2.2 \%$ in Sucha Beskidzka in Małopolska to over $150 \%$ in Drawsko Pomorskie in West Pomerania - $154.5 \%$, and Ustrzyki Dolne in Subcarpathia $176.9 \%$, cf. Fig. 1; values in excess of $100 \%$ were possible because one agricultural holding could submit applications for up to three packages under the agri-environmental programme).

The share of agricultural holdings in the CAP measures designed to improve the natural envi- 
ronment showed great spatial differences. In 93 poviats located mostly in central (Mazovia - 18 poviats, Łódź - 8 poviats) and southern Poland (Małopolska - 14 poviats, Subcarpathia - 13 poviats, Silesia - 15 poviats), a low level of the index was recorded, not exceeding $20 \%$. In turn, its high values - over $80 \%$ - were found in 36 poviats, mostly in north-western voivodeships: Lubuska Land (4 poviats), Pomerania (6) and West Pomerania (9), which accounted for as many as $53 \%$ of such poviats. The leaders in this group were 15 poviats with indices exceeding $100 \%$ in the voivodeships of Lublin (Włodawa), Lubuska Land (Krosno), Subcarpathia (Ustrzyki Dolne),

Table 2. CAP measures intended to improve the natural environment in the years 2004-2010: the Agri-environmental and Land afforestation programmes under RDP 2004-2006 and RDP 2007-2013.

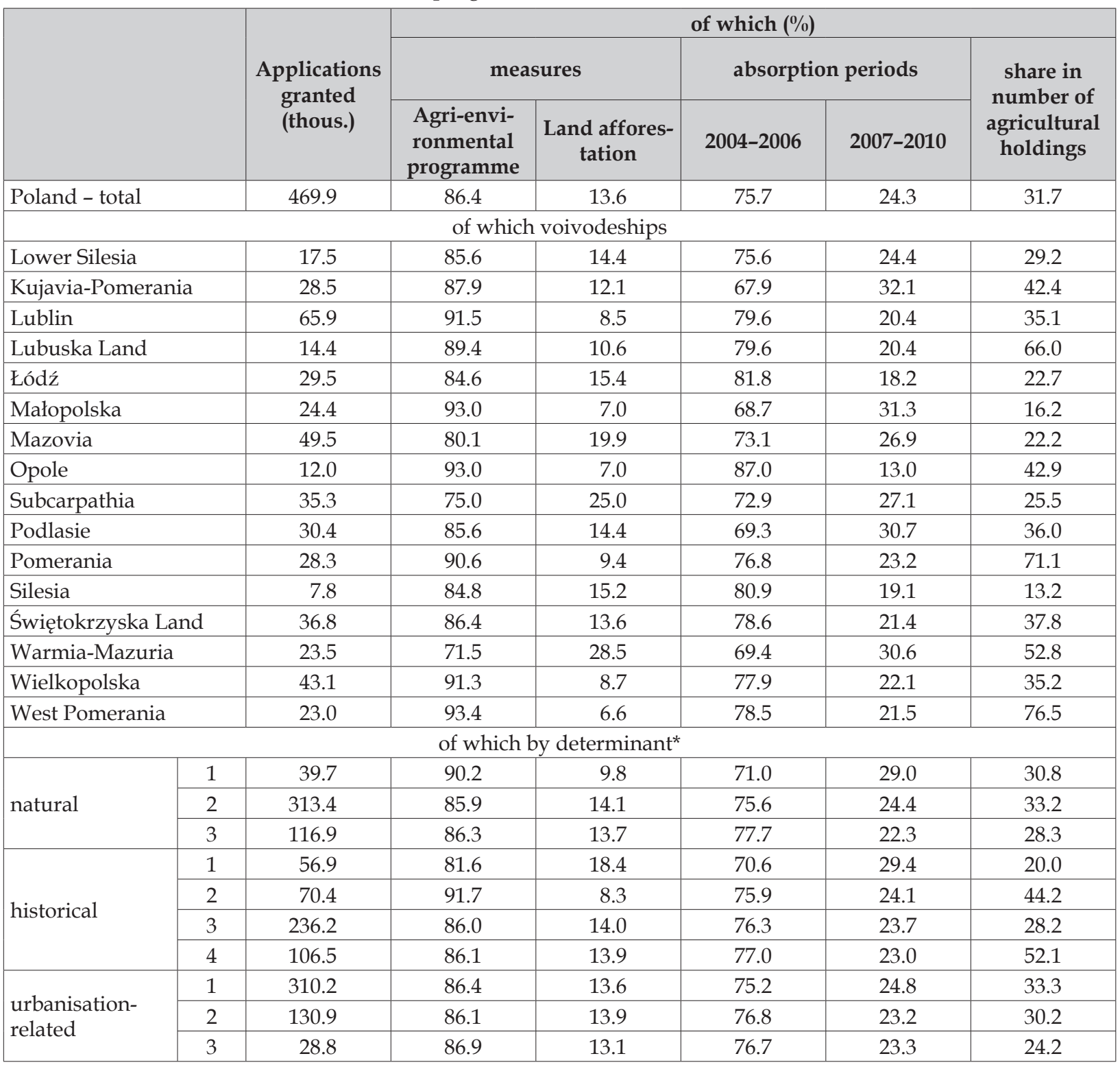

*AR\&MA poviat offices located in areas described in terms of the following determinants:

- natural: (1) highly unfavourable conditions - QAPS under 52 points, (2) unfavourable conditions - QAPS 52-72 points, (3) favourable conditions - QAPS over 72 points;

- historical: (1) former Austrian sector and within boundaries of interwar Poland, (2) former Prussian sector and within boundaries of interwar Poland, (3) former Russian sector and within boundaries of interwar Poland, (4) former Prussian sector and within boundaries of interwar Germany;

- urbanisation-related: (1) poorly urbanised poviats (located in predominantly rural sub-regions), (2) moderately urbanised poviats (located in intermediate sub-regions), and (3) highly urbanised poviats (located in predominantly urban sub-regions).

Source: own compilation on the basis of AR\&MA and GUS data. 

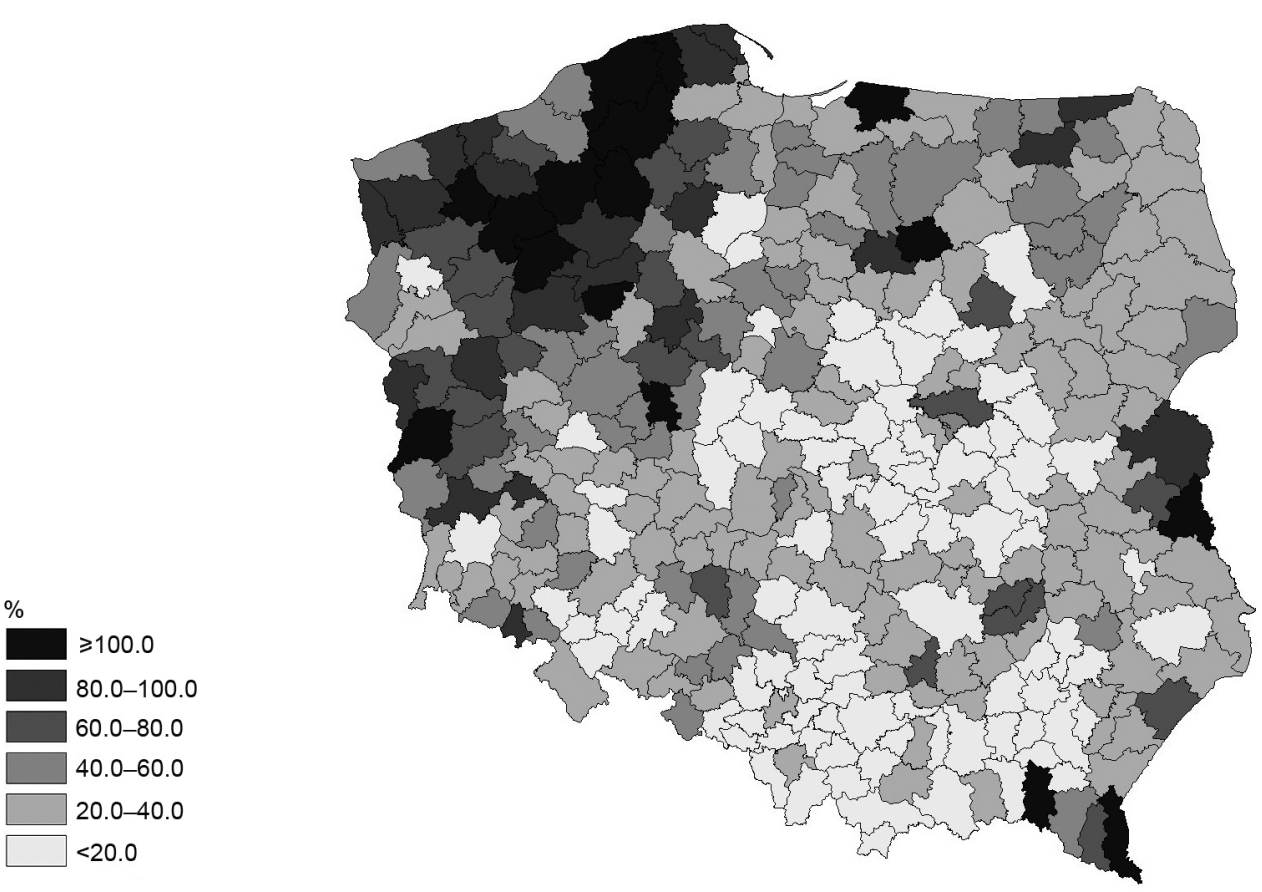

Fig. 1. CAP measures intended to improve the natural environment as per cent of the total number of agricultural holdings. Source: own compilation on the basis of AR\&MA and GUS data.

Pomerania (Bytów, Człuchów, Lębork, Słupsk), Warmia-Mazuria (Braniewo, Nida), Wielkopolska (Chodzież, Września), and West Pomerania (Drawsko Pomorskie, Łobez, Szczecinek, Wałcz).

The above spatial pattern shows agricultural holdings to display a lower activity under pro-environmental CAP measures in more highly urbanised areas - on average, $24.2 \%$ (as against $33.3 \%$ in poorly urbanised ones; cf. Table 2 ) and those historically situated in the former Austrian sector - on average, $20.0 \%$ (as against $52.1 \%$ in regions lying in the former Prussian sector and interwar Germany). There were no high values of the index in areas with unfavourable natural conditions (on average, 30.8\%), often characterised by low land-capability classes (the determinant of land afforestation) and large, legally protected areas of great natural value (the determinant of the agri-environmental programme).

\section{CAP measures intended to improve the agrarian-demographic structure of farms}

In comparison with the West European states, Polish agriculture has an unfavourable size struc- ture of farms and a deformed demographic structure of their operators. That is why of especially great significance among the CAP instruments were those designed to improve their agrarian-demographic structure, viz.:

1. Structural pensions; this measure embraced farmers of pre-retirement age (from 55 years old to the retirement threshold) and was intended to accelerate the process of generational exchange among farm operators and improve the farm-size structure. Over the years 2004-2010 there were 67.7 thous. applications, which meant the payment of 5,953 million zlotys (under RDP 2004-2006 and RDP 20072013).

2. Setting-up of young farmers; this measure was intended to improve the age structure of farm operators; the targets of the financial assistance were young farmers, up to 40 years of age, who started running an agricultural holding of their own. Over the study period a total of 30.2 thous. such subsidies were granted to the amount of 1,907 million zlotys (50 thous. zlotys per application under SOP_Agri in the years 2004-2006, and 75 thous. zlotys per application under RDP 2007-2013).

In the period under analysis, agricultural holdings submitted a total of 97.9 thous. applica- 
tions involving the improvement of their agrarian-demographic structure. In this group structural pensions predominated, with an average of $69.2 \%$ of applications (from ca. $60 \%$ in Lubuska Land and Wielkopolska to $83.7 \%$ in Subcarpathia), while the mean for the years 2004-2006 was $69.7 \%$ (from $65.5 \%$ in Wielkopolska to $74.7 \%$ in Lower Silesia; cf. Table 3).

The number of applications granted in the years 2004-2010 for the improvement of the agrarian-demographic structure of Polish farms accounted for an average of $6.6 \%$ of their total number. By voivodeship, this index ranged from ca. 3\% in Małopolska and Subcarpathia to over $11.7 \%$ in Kujavia-Pomerania (cf. Table 3).

By poviat, the disproportions varied from $1.2 \%$ in Chrzanów (Małopolska) and Skarżysko-Kamienna (Świętokrzyska Land) to $16.4 \%$ in Mogilno (Kujavia-Pomerania) and 16.9\% in Malbork (Pomerania). Low indices were noted in the agriculture of south-eastern Poland. For example, in the group of 14 poviats with an index

Table 3. CAP assistance measures intended to improve the agrarian-demographic structure of farms in the years 2004-2010: Structural pensions (under RDP 2004-2006 and RDP 2007-2013) and Setting-up of young farmers (under SOP_Agri 2004-2006 and RDP 2007-2013).

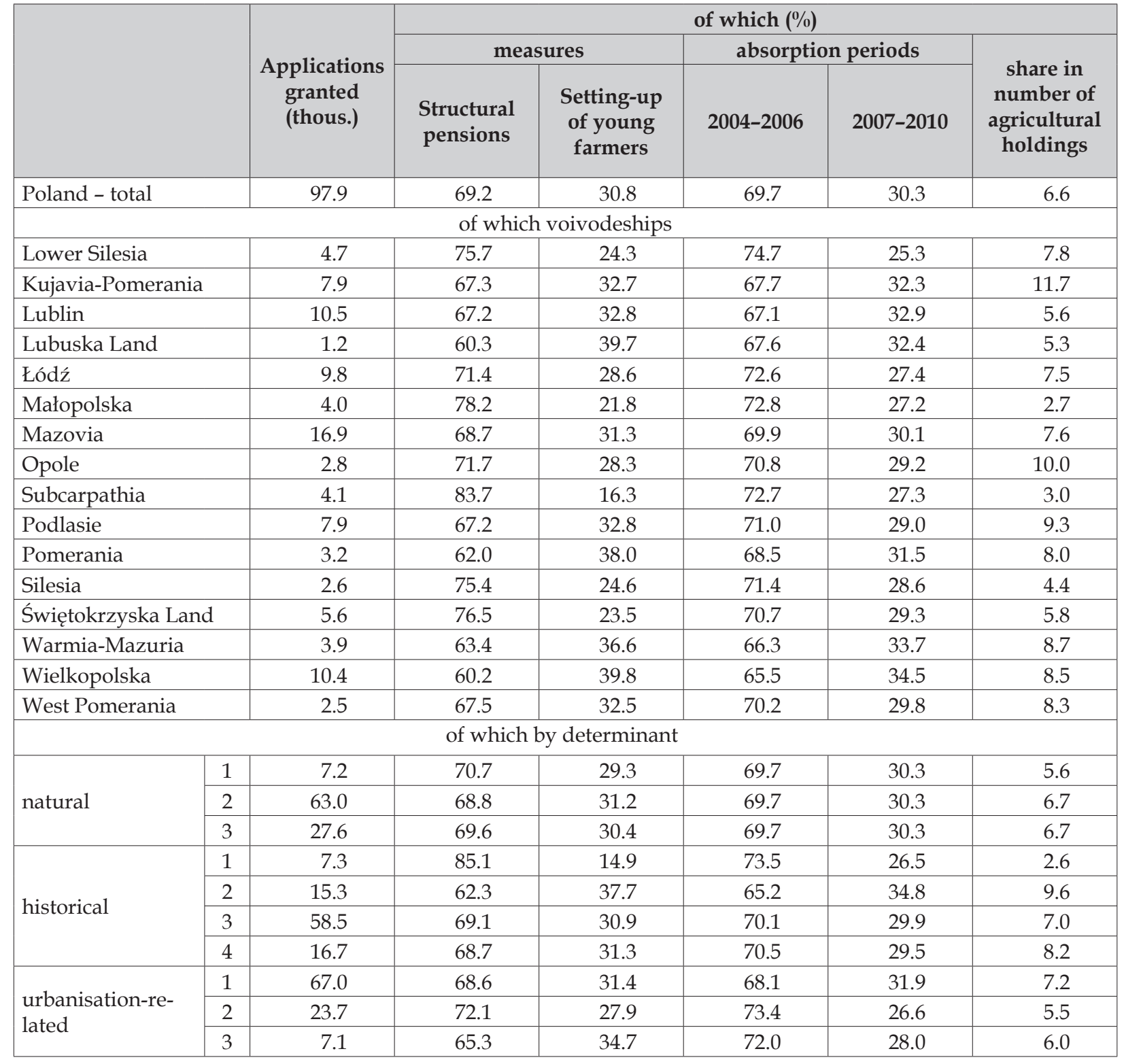

Source and explanations as in Table 2. 


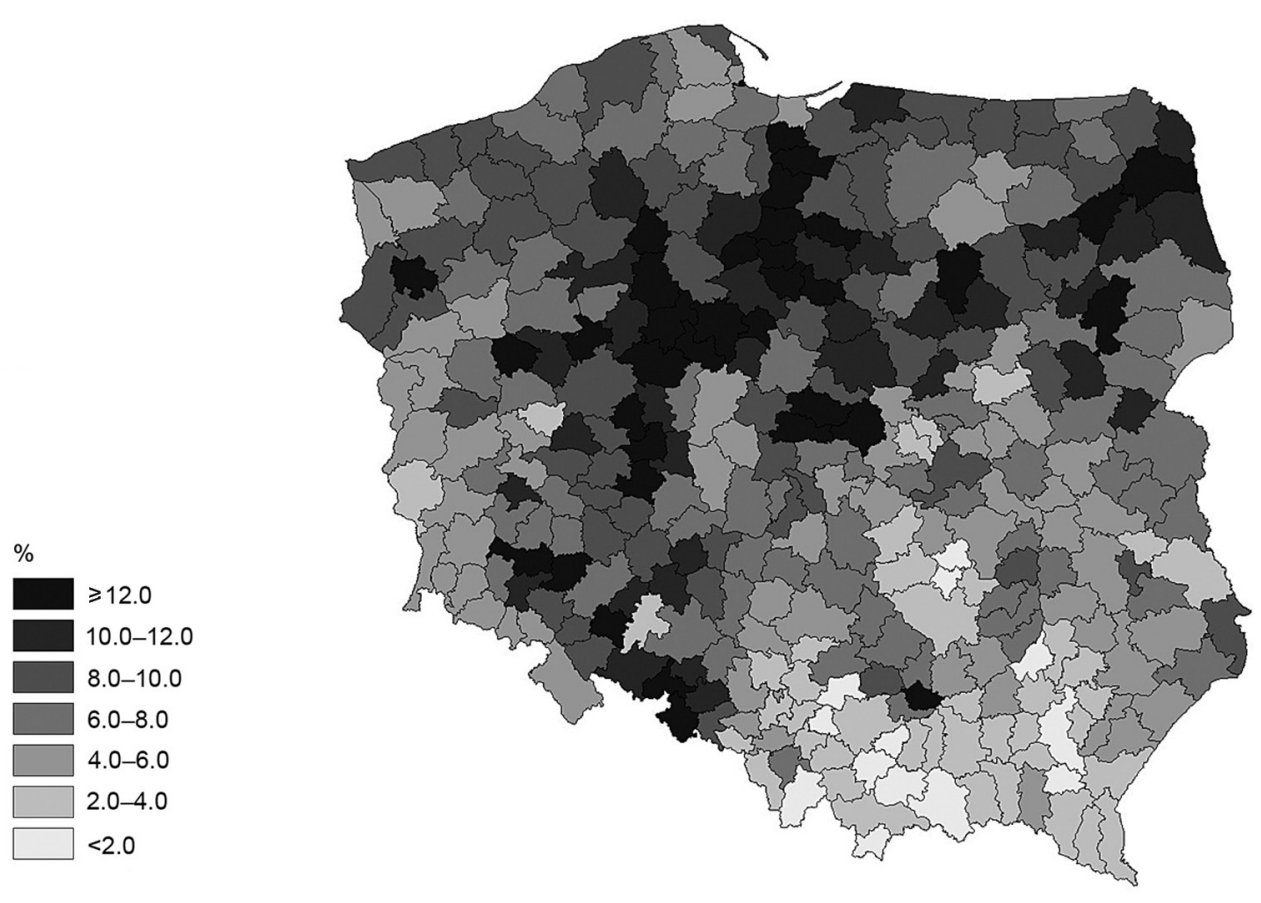

Fig. 2. CAP measures intended to improve the agrarian-demographic structure of farms as per cent of their total number. Source: own compilation on the basis of AR\&MA and GUS data.

of up to $2 \%$, as many as 13 were situated in the voivodeships of Małopolska, Subcarpathia, Silesia and Świętokrzyska Land (the exception being Szydłowiec poviat in Mazovia). In turn, high values (over 10\%) were recorded in 68 poviats concentrated in Lower Silesia (5 poviats) and Opole (7) in south-western Poland, Wielkopolska (13), Kujavia-Pomerania (15), Pomerania (5), Łódź (3) and Mazovia (7) in central and northern Poland, as well as Podlasie (8) and Warmia-Mazuria (3) in north-eastern Poland. Apart from this belt of voivodeships, such high values were only found in two poviats: Kazimierza Wielka in Świętokrzyska Land and Pyrzyce in West Pomerania (cf. Fig. 2).

The analysis of spatial differences in the number of agricultural holdings applying for CAP funds intended to improve their agrarian-demographic structure showed a great impact of the historical factor: low values of the index were recorded in areas with very small farms and a deformed demographic structure that once belonged to the Austrian sector (on average, 2.6\%), especially as compared with the lands of the former Prussian sector and interwar Poland (on average, $9.6 \%$; cf. Table 3). This territorial pattern of absorption has to be assessed unfavourably since it shows that the measures failed to bring the expected results.

\section{CAP measures intended to improve the technical equipment of agricultural holdings}

Especially important from the point of view of the development and greater competitiveness of Polish agriculture are CAP measures intended to improve the technical equipment of farms, viz.:

1. Investment on agricultural holdings; this measure, implemented in the years 2002-2004 (under SAPARD) and 2004-2006 (under SOP_ Agri), with a total of 37 thous. applications and payment of 3,030 million zlotys, largely involved refunds of a part of outlays for the construction or repair of buildings and for the purchase of machines and equipment.

2. Adjustment of agricultural holdings to EU standards; the aim was to adjust farms to Community standards in such fields as environmental protection, hygiene, animal welfare, and food safety. This measure was only implemented under RDP 2004-2006, when a total of 2,437 million zlotys were granted for 69.7 thous. of applications.

3. Development and improvement of farming-related physical infrastructure; the measure was intended to improve the equipment of farms 
with modern physical infrastructure, especially the kind important from an environmental point of view (e.g. water-and-sewage facilities). This measure was part of SOP_Agri in the years 2004-2006, when 3.4 thous. applications were granted and subsidised with 150 million zlotys.

4. Modernisation of agricultural holdings; the measure, implemented under RDP 2007-2013, supports investment intended to improve the technical and infrastructural equipment of agricultural holdings; in the years 2007-2010, 29.1 thous. such applications were granted and a subsidy of 3,435 million zlotys was paid. Between 2002 and 2010, under the many EU programmes (SAPARD in the years 2002-2004, RDP and SOP_Agri in the years 2004-2006, and

Table 4. CAP assistance measures intended to improve the technical equipment of agricultural holdings in the years 2002-2010: Investment on agricultural holdings (SAPARD, SOP_Agri 2004-2006), Adjustment of agricultural holdings to EU standards (RDP 2004-2006), Development of physical infrastructure (SOP_Agri 2004-2006), and Modernisation of agricultural holdings (RDP 2007-2013).

\begin{tabular}{|c|c|c|c|c|c|c|c|c|c|c|}
\hline & \multirow[b]{3}{*}{$\begin{array}{l}\text { Appli- } \\
\text { cations } \\
\text { granted } \\
\text { (thous.) }\end{array}$} & \multicolumn{8}{|c|}{ of which } \\
\hline & & & \multicolumn{4}{|c|}{ measures } & \multicolumn{3}{|c|}{ periods } & \multirow[b]{2}{*}{$\begin{array}{l}\text { share in } \\
\text { number } \\
\text { of agri- } \\
\text { cultural } \\
\text { holdings }\end{array}$} \\
\hline & & & $\begin{array}{l}\text { Invest- } \\
\text { ment on } \\
\text { agricul- } \\
\text { tural } \\
\text { holdings }\end{array}$ & $\begin{array}{c}\text { Adjust- } \\
\text { ment of } \\
\text { agricul- } \\
\text { tural } \\
\text { holdings } \\
\text { to EU } \\
\text { stand- } \\
\text { ards } \\
\end{array}$ & $\begin{array}{c}\text { Devel- } \\
\text { opment } \\
\text { of } \\
\text { physical } \\
\text { infra- } \\
\text { structure }\end{array}$ & $\begin{array}{l}\text { Modern- } \\
\text { isation } \\
\text { of agri- } \\
\text { cultural } \\
\text { holdings }\end{array}$ & $\begin{array}{c}2002- \\
2004\end{array}$ & $\begin{array}{c}2004- \\
2006\end{array}$ & $\begin{array}{c}2007- \\
2010\end{array}$ & \\
\hline \multicolumn{2}{|l|}{ Poland - total } & 139.7 & 26.8 & 49.9 & 2.4 & 20.9 & 9.3 & 69.9 & 20.9 & 9.4 \\
\hline \multicolumn{11}{|c|}{ of which voivodeships } \\
\hline \multicolumn{2}{|l|}{ Lower Silesia } & 2.6 & 38.7 & 23.5 & 1.4 & 36.4 & 10.1 & 53.6 & 36.4 & 4.3 \\
\hline \multicolumn{2}{|c|}{ Kujavia-Pomerania } & 18.4 & 16.3 & 68.3 & 1.1 & 14.3 & 6.0 & 79.7 & 14.3 & 27.4 \\
\hline \multicolumn{2}{|c|}{ Lublin } & 10.7 & 41.6 & 28.1 & 6.1 & 24.3 & 13.5 & 62.2 & 24.3 & 5.7 \\
\hline \multicolumn{2}{|l|}{ Lubuska Land } & 1.6 & 25.0 & 34.7 & 2.2 & 38.2 & 8.5 & 53.3 & 38.2 & 7.1 \\
\hline \multicolumn{2}{|l|}{ Łódź } & 11.0 & 29.6 & 50.7 & 2.6 & 17.1 & 8.0 & 74.9 & 17.1 & 8.4 \\
\hline \multicolumn{2}{|l|}{ Małopolska } & 4.1 & 49.2 & 21.8 & 4.0 & 24.8 & 20.0 & 55.0 & 24.9 & 2.7 \\
\hline \multicolumn{2}{|l|}{ Mazovia } & 26.0 & 28.0 & 51.5 & 2.0 & 18.6 & 12.1 & 69.3 & 18.6 & 11.7 \\
\hline \multicolumn{2}{|l|}{ Opole } & 2.5 & 33.0 & 23.0 & 7.4 & 36.7 & 8.1 & 55.3 & 36.7 & 9.0 \\
\hline \multicolumn{2}{|l|}{ Subcarpathia } & 2.1 & 35.6 & 31.0 & 4.7 & 28.7 & 10.4 & 60.8 & 28.7 & 1.5 \\
\hline \multicolumn{2}{|l|}{ Podlasie } & 11.8 & 20.9 & 49.4 & 3.5 & 26.1 & 3.8 & 70.1 & 26.1 & 14.0 \\
\hline \multicolumn{2}{|l|}{ Pomerania } & 7.2 & 20.6 & 60.8 & 1.9 & 16.7 & 8.8 & 74.5 & 16.7 & 18.1 \\
\hline \multicolumn{2}{|c|}{ Silesia } & 2.0 & 37.2 & 31.3 & 3.6 & 27.9 & 10.8 & 61.4 & 27.9 & 3.4 \\
\hline \multicolumn{2}{|c|}{ Świętokrzyska Land } & 6.1 & 47.0 & 22.2 & 4.1 & 26.8 & 19.1 & 54.2 & 26.8 & 6.3 \\
\hline \multicolumn{2}{|c|}{ Warmia-Mazuria } & 7.1 & 18.8 & 57.8 & 0.9 & 22.5 & 5.0 & 72.5 & 22.5 & 16.0 \\
\hline \multicolumn{2}{|l|}{ Wielkopolska } & 23.6 & 20.1 & 61.5 & 1.1 & 17.3 & 7.3 & 75.4 & 17.3 & 19.3 \\
\hline \multicolumn{2}{|l|}{ West Pomerania } & 2.9 & 26.5 & 39.2 & 1.7 & 32.6 & 5.4 & 62.0 & 32.6 & 9.5 \\
\hline \multicolumn{11}{|c|}{ of which by determinant } \\
\hline \multirow{3}{*}{ natural } & 1 & 13.5 & 13.9 & 66.0 & 1.7 & 18.4 & 3.1 & 78.5 & 18.4 & 10.5 \\
\hline & 2 & 93.2 & 25.9 & 51.0 & 2.5 & 20.6 & 8.7 & 70.8 & 20.6 & 9.9 \\
\hline & 3 & 32.9 & 34.5 & 40.2 & 2.6 & 22.7 & 13.5 & 63.8 & 22.7 & 8.0 \\
\hline \multirow{4}{*}{ historical } & 1 & 4.7 & 42.6 & 27.1 & 4.4 & 25.8 & 14.3 & 59.8 & 25.9 & 1.7 \\
\hline & 2 & 35.7 & 18.1 & 64.8 & 1.2 & 15.9 & 6.4 & 77.6 & 15.9 & 22.4 \\
\hline & 3 & 80.1 & 29.6 & 46.7 & 3.0 & 20.8 & 10.5 & 68.7 & 20.8 & 9.6 \\
\hline & 4 & 19.2 & 27.4 & 41.3 & 2.1 & 29.1 & 8.0 & 62.9 & 29.1 & 9.4 \\
\hline \multirow{3}{*}{$\begin{array}{l}\text { urbanisation- } \\
\text { related }\end{array}$} & 1 & 103.2 & 23.5 & 54.4 & 2.3 & 19.8 & 7.2 & 73.0 & 19.8 & 11.1 \\
\hline & 2 & 25.7 & 36.3 & 35.4 & 3.0 & 25.3 & 15.4 & 59.3 & 25.3 & 5.9 \\
\hline & 3 & 10.8 & 35.7 & 41.9 & 2.2 & 20.2 & 14.5 & 65.3 & 20.2 & 9.1 \\
\hline
\end{tabular}

Source and explanations as in Table 2. 

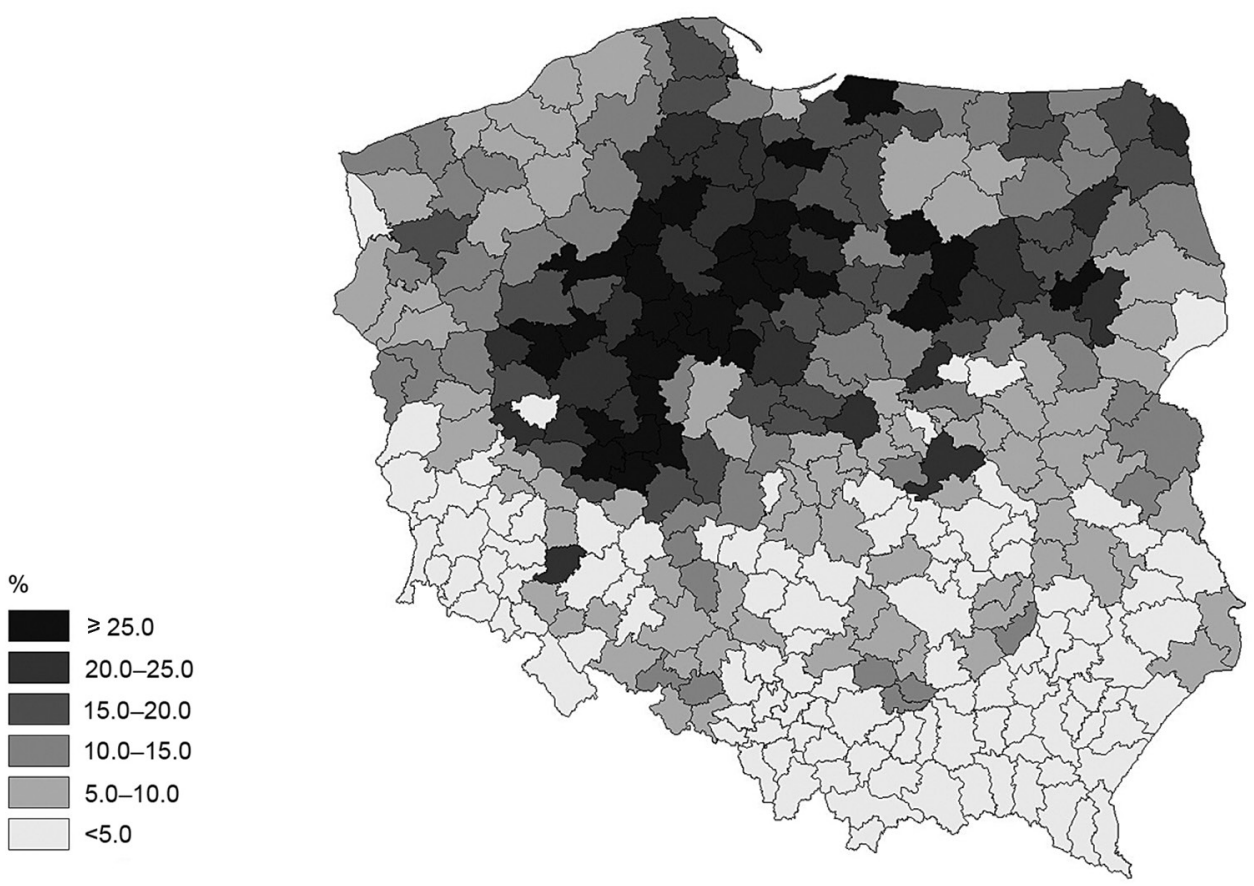

Fig. 3. CAP measures intended to improve the technical equipment of agriculture as per cent of the total number of agricultural holdings.

Source: own compilation on the basis of AR\&MA and GUS data.

RDP in the years 2007-2010), agricultural holdings in Poland were granted nearly 140 thous. applications involving an improvement of their technical equipment. In this group the most popular measure was Adjustment of agricultural holdings to EU standards, implemented under RDP 2004-2006: it accounted for an average of $49.9 \%$ of applications (by voivodeship, from under 25\% in Lower Silesia, Małopolska, Opole and Świętokrzyska Land to over $60 \%$ in Kujavia-Pomerania, Pomerania and Wielkopolska). This gave the period 2004-2006 a high position in the implementation of the above measures, with an average of $69.9 \%$ (by voivodeship, from $53-55 \%$ in Lower Silesia, Lubuska Land, Małopolska and Świętokrzyska Land to nearly $80 \%$ in Kujavia-Pomerania; cf. Table 4).

The number of applications intended to improve the technical state of agriculture accounted for $9.4 \%$ of all farms. This index showed wide spatial differences, both by region (from $1.5 \%$ in Subcarpathia to $27.4 \%$ in Kujavia-Pomerania; cf. Table 4), and by poviat (from $0.3 \%$ in Będzin in Silesia and Zakopane in Małopolska to $41.5 \%$ in Żnin in Kujavia-Pomerania; cf. Fig. 3).

A low level of activity of agricultural holdings in obtaining EU funds to improve their technical equipment was found in southern Poland (most distinctly on lands belonging to the former Austrian sector - on average, $1.7 \%$ ), with small average sizes of farms making it hard to spend money on agricultural technology rationally. In turn, high values of the index - in excess of $25 \%$ - were recorded in 30 poviats, largely situated in $\mathrm{Ku}-$ javia-Pomerania (13) and Wielkopolska (10), historically within the former Prussian sector and interwar Poland (on average, $22.4 \%$; cf. Table 4). In terms of the impact of the historical factor, it was also demonstrated that the northern and western lands belonging to Germany in the interwar period and now characterised by the largest mean farm sizes in Poland, did not display any great activity in obtaining EU funds for improvement of their technical equipment. This is indicative of the extensification of agricultural production taking place there.

\section{CAP measures intended to improve the income situation of agricultural holdings}

In the years 2002-2010, CAP funds were also designed to improve the income situation of agricultural holdings in Poland. Their task was to 
stimulate both, an increase in the commodification of agriculture and the extra-agricultural activity of farms, and they involved two measures:

1. Support for semi-subsistence farms undergoing restructuring; or financial assistance necessary to help preserve the financial liquidity of farms with a small production scale (up to 4 ESU). This measure was only established under RDP 2004-2006; it embraced 157.7 thous. agricultural holdings and involved spending 3,062 million zlotys.
2. Diversification into non-agricultural activities; the aim was to support investment projects designed to start an additional economic activity on farms (e.g. agro-tourism, or services for agriculture and small-scale processing of produce); those measures were implemented in the years 2003-2004 under SAPARD (including the scheme Creation of additional income sources on agricultural holdings), in 2004-2006 (Diversification of agricultural and agriculture-related activity to ensure a diver-

Table 5. CAP assistance measures intended to improve the income situation of agricultural holdings in the years 2002-2010: Support for semi-subsistence farms undergoing restructuring (RDP 2004-2006) and Diversification into non-agricultural activities (SAPARD, SOP_Agri, RDP 2007-2013).

\begin{tabular}{|c|c|c|c|c|c|c|c|c|}
\hline & & \multirow[b]{3}{*}{$\begin{array}{l}\text { Appli- } \\
\text { cations } \\
\text { granted } \\
\text { (thous.) }\end{array}$} & \multicolumn{6}{|c|}{ of which } \\
\hline & & & \multicolumn{2}{|c|}{ measures } & \multicolumn{3}{|c|}{ periods } & \multirow[b]{2}{*}{$\begin{array}{c}\text { share in } \\
\text { number of } \\
\text { agricultural } \\
\text { holdings }\end{array}$} \\
\hline & & & $\begin{array}{l}\text { Support for } \\
\text { semi-sub- } \\
\text { sistence } \\
\text { farms }\end{array}$ & $\begin{array}{l}\text { Diversifi- } \\
\text { cation into } \\
\text { non-agri- } \\
\text { cultural } \\
\text { activities }\end{array}$ & 2002-2004 & 2004-2006 & 2007-2010 & \\
\hline \multicolumn{2}{|l|}{ Poland - total } & 166 & 94.8 & 5.2 & 0.9 & 97.3 & 1.8 & 11.2 \\
\hline \multicolumn{9}{|c|}{ of which voivodeships } \\
\hline \multicolumn{2}{|l|}{ Lower Silesia } & 3.2 & 92.9 & 7.1 & 1.6 & 96.0 & 2.4 & 5.4 \\
\hline \multicolumn{2}{|l|}{ Kujavia-Pomerania } & 6.6 & 93.2 & 6.8 & 1.0 & 96.7 & 2.3 & 9.8 \\
\hline \multicolumn{2}{|l|}{ Lublin } & 29.1 & 95.6 & 4.5 & 0.4 & 98.3 & 1.3 & 15.5 \\
\hline \multicolumn{2}{|l|}{ Lubuska Land } & 1.3 & 89.3 & 10.7 & 3.6 & 92.2 & 4.2 & 5.8 \\
\hline \multicolumn{2}{|l|}{ Łódź } & 20.3 & 97.5 & 2.5 & 0.3 & 98.8 & 0.9 & 15.6 \\
\hline \multicolumn{2}{|l|}{ Małopolska } & 15.2 & 94.6 & 5.4 & 0.9 & 97.5 & 1.6 & 10.1 \\
\hline \multicolumn{2}{|l|}{ Mazovia } & 26.2 & 96.3 & 3.7 & 0.3 & 98.0 & 1.7 & 11.8 \\
\hline \multicolumn{2}{|l|}{ Opole } & 1.9 & 87.6 & 12.4 & 1.5 & 92.5 & 5.9 & 6.9 \\
\hline \multicolumn{2}{|l|}{ Subcarpathia } & 10.9 & 93.7 & 6.3 & 1.7 & 96.4 & 1.9 & 7.9 \\
\hline \multicolumn{2}{|l|}{ Podlasie } & 8.3 & 92.4 & 7.6 & 1.9 & 95.4 & 2.7 & 9.9 \\
\hline \multicolumn{2}{|l|}{ Pomerania } & 4.0 & 91.8 & 8.2 & 3.0 & 94.5 & 2.5 & 10.1 \\
\hline \multicolumn{2}{|l|}{ Silesia } & 3.0 & 88.1 & 11.9 & 2.6 & 93.4 & 4.0 & 5.1 \\
\hline \multicolumn{2}{|l|}{ Świętokrzyska Land } & 20.8 & 97.1 & 2.9 & 0.3 & 98.8 & 0.9 & 21.4 \\
\hline \multicolumn{2}{|l|}{ Warmia-Mazuria } & 2.9 & 86.5 & 13.5 & 4.3 & 91.0 & 4.7 & 6.6 \\
\hline \multicolumn{2}{|l|}{ Wielkopolska } & 10.4 & 92.4 & 7.6 & 1.0 & 95.5 & 3.5 & 8.5 \\
\hline \multicolumn{2}{|l|}{ West Pomerania } & 1.9 & 90.3 & 9.7 & 2.5 & 93.8 & 3.7 & 6.3 \\
\hline \multicolumn{9}{|c|}{ of which by determinant } \\
\hline \multirow{3}{*}{ natural } & 1 & 12.1 & 93.5 & 6.5 & 1.6 & 96.5 & 2.0 & 9.4 \\
\hline & 2 & 102.0 & 94.9 & 5.1 & 0.9 & 97.2 & 1.9 & 10.8 \\
\hline & 3 & 52.2 & 95.0 & 5.0 & 0.7 & 97.5 & 1.8 & 12.6 \\
\hline \multirow{4}{*}{ historical } & 1 & 22.5 & 93.4 & 6.6 & 1.6 & 96.5 & 1.9 & 7.9 \\
\hline & 2 & 12.5 & 90.7 & 9.3 & 1.6 & 94.6 & 3.8 & 7.9 \\
\hline & 3 & 118.7 & 96.1 & 3.9 & 0.5 & 98.1 & 1.4 & 14.2 \\
\hline & 4 & 12.6 & 89.4 & 10.6 & 2.9 & 93.2 & 3.9 & 6.2 \\
\hline \multirow{3}{*}{$\begin{array}{l}\text { urbanisation- } \\
\text { related }\end{array}$} & 1 & 118.9 & 95.3 & 4.7 & 0.8 & 97.5 & 1.8 & 12.8 \\
\hline & 2 & 35.7 & 93.7 & 6.3 & 1.3 & 96.6 & 2.1 & 8.3 \\
\hline & 3 & 11.6 & 93.7 & 6.3 & 1.0 & 96.9 & 2.1 & 9.8 \\
\hline
\end{tabular}

Source and explanations as in Table 2. 
sity of ventures or alternative sources of income, under SOP_Agri), and 2007-2009 (Diversification into non-agricultural activities, under RDP 2007-2013). A total of 7.1 thous. applications were granted in this field, which involved a financial support of 571 million zlotys.

In sum, 166.3 thous. applications concerning an improvement of the income situation of agricultural holdings were granted over the study period. There was a clear predominance of support for semi-subsistence farms - on average, $94.8 \%$ of applications (from $86.5 \%$ in Warmia-Mazuria to 97.5\% in Łódź) as well as applications submitted in the years 2004-2006 - on average, 97.3\% (from 91.0\% in Warmia-Mazuria to $88.8 \%$ in Łódź and Świętokrzyska Land; cf. Table 5). This was largely due to a great number of applications submitted under RDP 2004-2006 for support for semi-subsistence farms (close to 160 thous.), this form of EU support being abandoned in the next period as a result of its unfavourable assessment. While providing an annual financial support of 5 thous. zlotys (ca. $€ 1,200$ ), this measure contributed very little to an increase in the commodification of agricultural production and was mostly a form of social support.
On average, the EU assistance measures intended to improve the income situation of farming families embraced $11.2 \%$ of agricultural holdings in Poland. This index ranged, by voivodeship, from $5.1 \%$ in Silesia to $21.4 \%$ in Świętokrzyska Land, and by poviat, from $1.4 \%$ in Tychy in Silesia to 38.9\% in Kazimierza Wielka in Świętokrzyska Land.

The index had low values, up to $5 \%$, mostly in poviats situated in the west of the country: Lower Silesia (10 poviats), Silesia (13 poviats), Wielkopolska (10 poviats) and West Pomerania (8 poviats). High figures were recorded primarily in poviats of central and eastern Poland, especially in Lublin and Świętokrzyska Land, where as many as 12 poviats (out of the total of 20) with the highest - over $20 \%$ - values of the index were located (cf. Fig. 4). As a rule, those poviats demonstrated a low level of commodification of their agriculture. This spatial pattern means that the RDP 2004-2006 measure can be assessed as having achieved its purpose.

This spatial pattern reveals an above-average activity of agricultural holdings in poviats situated on lands of the former Russian sector $(14.2 \%$, as against $6.2 \%$ in the former Prussian sector and interwar Germany). Elevated values of the index

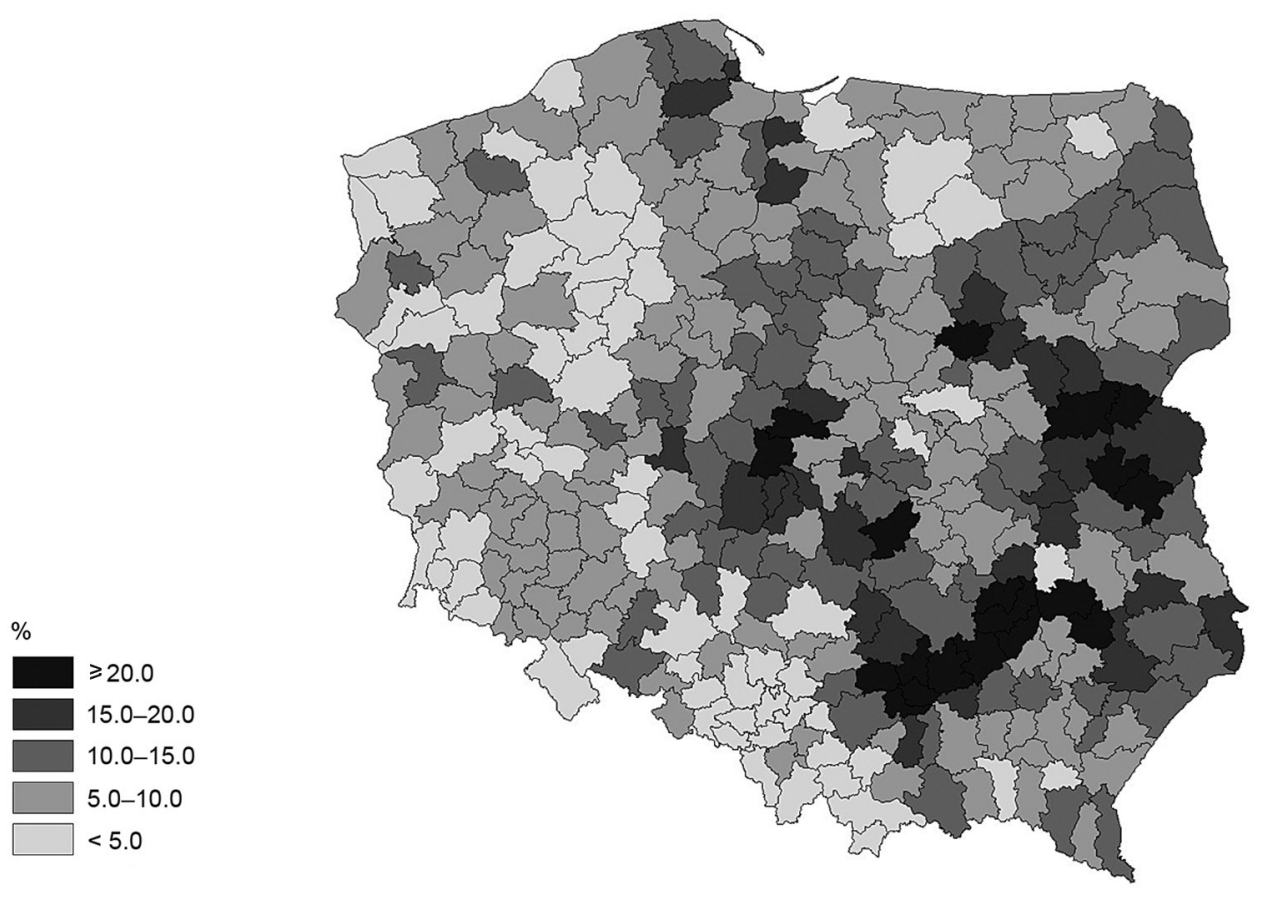

Fig. 4. CAP measures intended to improve the income situation of farming families as per cent of the total number of agricultural holdings.

Source: own compilation on the basis of AR\&MA and GUS data. 
were also found in poviats with favourable natural conditions $(12.6 \%)$ and a low urbanisation level (12.8\%; cf. Table 5).

\section{Activity of agricultural holdings in obtaining CAP funds: a synthetic approach}

The conducted analysis demonstrated that in the years 2002-2010 there was a complex system of subsidies addressed to agricultural holdings in Poland embracing (apart from area payments and LFAs) ten operational measures implemented under the programmes: SAPARD (the years 2002-2004), RDP and SOP_Agri (the years 20042006), and RDP 2007-2013 (the analysis covered the period 2007-2010). There were wide spatial differences in the use that farms made of those measures. An analysis was made of the level and structure of their activity in this field.

\subsection{Level of activity}

The total number of EU assistance measures granted to agricultural holdings in Poland over the years 2004-2010 (the analysis covered close to 874 thous. applications) showed great differences by voivodeship: from 15.5 thous. in Silesia and 19.2 thous. in Opole to 116.3 thous. in Lublin and 118.6 thous. in Mazovia (cf. Table 6). By poviat, the figures ranged from 199 applications in Chrzanów (Małopolska) to 19,668 in Biała Podlaska (Lublin).

The synthetic index adopted to measure the level of activity of agricultural holdings in obtaining EU funds was the number of applications granted under the operational CAP programmes as per cent of the total number of farms conducting agricultural activity. The average for the country as a whole was $58.9 \%$, the figure varying widely by region, from $26.2 \%$ in Silesia to over $100 \%$ in Pomerania (107.3\%) and West Pomerania $(100.7 \%$, the number of applications granted being higher here than that of farms; cf. Table 6). By poviat, the average ranged from under 10\% in two poviats of Małopolska (Sucha Beskidz$\mathrm{ka}, 8.6 \%$, and Wadowice, $9.5 \%$ ) to over $170 \%$ in four poviats: of Pomerania (Lębork, 170.4\%), Wielkopolska (Września 177.0\%), West Pomerania (Drawsko Pomorskie, 179.7) and Subcarpathia (Ustrzyki Dolne, 196.7\%).

High indices of farm activity in obtaining EU funds were often recorded in areas with a high proportion of agri-environmental subsidies in the structure of applications. Since one agricultural holding could apply for up to three agri-environmental packages, this determinant was responsible for the appearance of 55 poviats with indices exceeding $100 \%$, including a distinct, territorially compact pattern of 36 poviats in the north-western part of the country embracing Kujavia-Pomerania, Lubuska Land, Pomerania, Wielkopolska, and West Pomerania (cf. Fig. 5).

The analysis showed that the territorial distribution of the index of farm activity in obtaining CAP funds was correlated with the historical and urbanisation-related factors. It had high values in areas of the former Prussian sector, especially those belonging to Poland in the interwar period, where the level of farming practices is higher (on average, $84.1 \%$ ). Elevated values of the index were also found in poviats most poorly urbanised (on average, 64.3\%), which demonstrates that the EU funds had a good effect as a factor helping to reduce territorial disproportions in the socio-economic development of rural areas.

Despite the fact that the agri-environmental programme preferring areas with unfavourable natural conditions enjoyed great popularity with farmers, the analysis did not show the index to have high values there (on average, 56.2; cf. Table 6). This is indicative of ecological attitudes becoming increasingly popular in agriculture also in areas with favourable natural farming conditions.

\subsection{Structure of activity}

An analysis was also made of spatial differences in the structure of activity of agricultural holdings in applying for assistance as divided into the groups of measures considered. Because of big differences in the number of applications under measures concerning the improvement of natural conditions (470 thous.), agrarian-demographic structure (98 thous.), technical equipment of farms (140 thous.), and their income 
situation (166 thous.), the analysis was based on the share of those measures in the total number of agricultural holdings presented in the form of normalised values, which made it possible to compare the spatial patterns investigated (Racine, Reymond 1977; cf. Table 6). This approach allowed a bi-directional analysis of the structure of absorption of EU funds to establish differences in their influence on selected segments of agriculture (a detailed approach) and to find an element leading in the absorption structure (a general approach).

The spatial structure of EU assistance granted to agricultural holdings varied sharply. This is corroborated by an analysis of measures intended to improve a selected segment of the spatial structure of agriculture by group (natural environment - E, agrarian-demographic structure - A, technical equipment - T, and income situation - I), in terms of two levels of farm activity:

Table 6. Selected elements of assessment of the level and structure of the activity of agricultural holdings in obtaining funds under the various operational CAP programmes in the years 2002-2010.

\begin{tabular}{|c|c|c|c|c|c|c|c|c|c|}
\hline & & \multicolumn{2}{|c|}{ Applications - total } & \multicolumn{4}{|c|}{$\begin{array}{l}\text { of which measures intended to improve } \\
\text { selected segment of spatial structure of } \\
\text { agriculture (normalised mean) }\end{array}$} & \multicolumn{2}{|c|}{$\begin{array}{c}\text { Structure of applica- } \\
\text { tions }\end{array}$} \\
\hline & & in thous. & $\begin{array}{l}\text { as } \% \text { of } \\
\text { agricul- } \\
\text { tural } \\
\text { holdings }\end{array}$ & $\begin{array}{l}\text { natural } \\
\text { environ- } \\
\text { ment }(E)\end{array}$ & $\begin{array}{l}\text { agrari- } \\
\text { an-demo- } \\
\text { graphic } \\
\text { structure } \\
\text { (A) }\end{array}$ & $\begin{array}{l}\text { technical } \\
\text { equip- } \\
\text { ment }(T)\end{array}$ & $\begin{array}{l}\text { income } \\
\text { situation } \\
\text { (I) }\end{array}$ & $\begin{array}{l}\text { structural } \\
\text { type }\end{array}$ & $\begin{array}{l}\text { leading } \\
\text { element } \\
\text { in struc- } \\
\text { ture }\end{array}$ \\
\hline \multicolumn{2}{|l|}{ Poland - total } & 873.8 & 58.9 & 0.00 & 0.00 & 0.00 & 0.00 & - & - \\
\hline \multicolumn{10}{|c|}{ of which voivodeships } \\
\hline \multicolumn{2}{|l|}{ Lower Silesia } & 28.1 & 46.8 & -0.08 & 0.37 & -0.57 & -0.52 & IV & A \\
\hline \multicolumn{2}{|l|}{ Kujavia-Pomerania } & 61.3 & 91.3 & 0.36 & 1.49 & 2.02 & -0.12 & XIII & $\mathrm{T}$ \\
\hline \multicolumn{2}{|l|}{ Lublin } & 116.3 & 61.9 & 0.12 & -0.30 & -0.42 & 0.39 & IX & $\mathrm{I}$ \\
\hline \multicolumn{2}{|l|}{ Lubuska Land } & 18.4 & 84.2 & 1.15 & -0.38 & -0.26 & -0.48 & VI & $E$ \\
\hline \multicolumn{2}{|l|}{ Eódź } & 70.6 & 54.3 & -0.30 & 0.28 & -0.11 & 0.40 & XI & I \\
\hline \multicolumn{2}{|l|}{ Małopolska } & 47.8 & 31.7 & -0.51 & -1.14 & -0.75 & -0.10 & I & $\mathrm{I}$ \\
\hline \multicolumn{2}{|l|}{ Mazovia } & 118.6 & 53.2 & -0.32 & 0.29 & 0.25 & 0.05 & XII & A \\
\hline \multicolumn{2}{|l|}{ Opole } & 19.2 & 68.7 & 0.38 & 0.99 & -0.05 & -0.39 & VI & $\mathrm{A}$ \\
\hline \multicolumn{2}{|l|}{ Subcarpathia } & 52.5 & 37.9 & -0.20 & -1.06 & -0.89 & -0.30 & I & $E$ \\
\hline \multicolumn{2}{|l|}{ Podlasie } & 58.3 & 69.2 & 0.15 & 0.80 & 0.51 & -0.12 & XIII & $\mathrm{A}$ \\
\hline \multicolumn{2}{|l|}{ Pomerania } & 42.7 & 107.3 & 1.32 & 0.41 & 0.97 & -0.10 & XIII & $\mathrm{E}$ \\
\hline \multicolumn{2}{|l|}{ Silesia } & 15.5 & 26.2 & -0.61 & -0.64 & -0.67 & -0.54 & I & $\mathrm{I}$ \\
\hline \multicolumn{2}{|c|}{ Świętokrzyska Land } & 69.3 & 71.2 & 0.20 & -0.24 & -0.35 & 0.91 & IX & $\mathrm{I}$ \\
\hline \multicolumn{2}{|c|}{ Warmia-Mazuria } & 37.4 & 84.1 & 0.71 & 0.61 & 0.74 & -0.41 & XIII & $\mathrm{T}$ \\
\hline \multicolumn{2}{|l|}{ Wielkopolska } & 87.5 & 71.6 & 0.12 & 0.56 & 1.12 & -0.24 & XIII & $\mathrm{T}$ \\
\hline \multicolumn{2}{|l|}{ West Pomerania } & 30.2 & 100.7 & 1.49 & 0.51 & 0.01 & -0.44 & XIII & $\mathrm{E}$ \\
\hline \multicolumn{10}{|c|}{ of which by determinant } \\
\hline \multirow{3}{*}{ natural } & 1 & 72.5 & 56.2 & -0.03 & -0.30 & 0.12 & -0.16 & III & $\mathrm{T}$ \\
\hline & 2 & 571.7 & 60.6 & 0.05 & 0.03 & 0.05 & -0.03 & XIII & $\mathrm{T}$ \\
\hline & 3 & 229.6 & 55.7 & -0.11 & 0.03 & -0.16 & 0.13 & XI & I \\
\hline \multirow{4}{*}{ historical } & 1 & 91.4 & 32.1 & -0.39 & -1.17 & -0.87 & -0.29 & $\mathrm{I}$ & $\mathrm{I}$ \\
\hline & 2 & 133.9 & 84.1 & 0.42 & 0.88 & 1.47 & -0.30 & XIII & $\mathrm{T}$ \\
\hline & 3 & 493.5 & 59.0 & -0.11 & 0.12 & 0.02 & 0.27 & XII & I \\
\hline & 4 & 155.0 & 75.8 & 0.68 & 0.46 & 0.00 & -0.45 & VI & $E$ \\
\hline \multirow{3}{*}{$\begin{array}{l}\text { urbanisation- } \\
\text { related }\end{array}$} & 1 & 599.4 & 64.3 & 0.05 & 0.17 & 0.19 & 0.14 & XVI & $\mathrm{T}$ \\
\hline & 2 & 216.1 & 49.9 & -0.05 & -0.32 & -0.39 & -0.26 & I & $\mathrm{E}$ \\
\hline & 3 & 58.4 & 49.0 & -0.25 & -0.18 & -0.04 & -0.13 & I & $\mathrm{T}$ \\
\hline
\end{tabular}

Source: own compilation on the basis of AR\&MA and GUS data; explanations as in Table 2. 


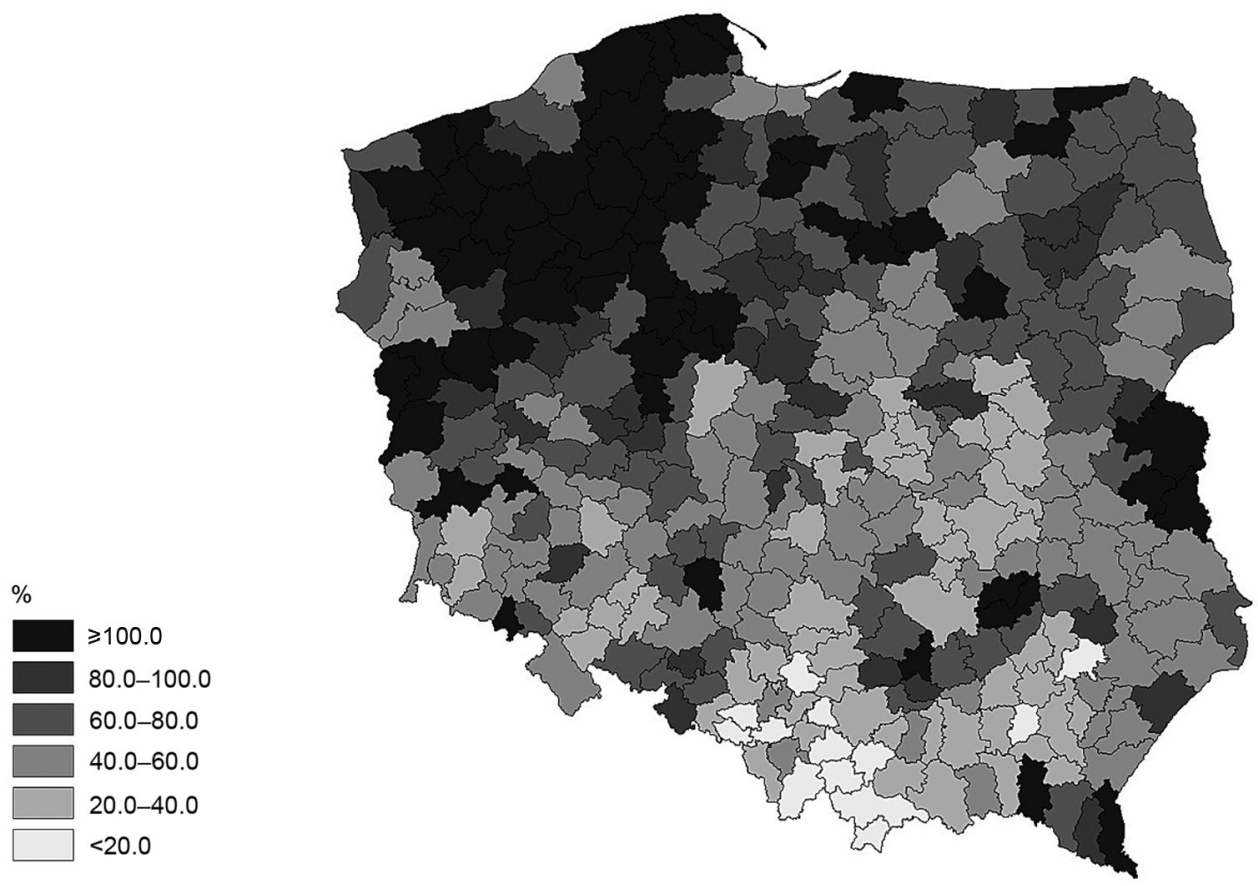

Fig. 5. Index of the activity of agricultural holdings in obtaining CAP funds (applications under the operational programmes as \% of the total number of farms).

Source: own compilation on the basis of AR\&MA and GUS data.

low (below-average - the symbol "1") and high (above-average - the symbol "2"), within which as many as 16 structural types were distinguished (cf. Table 7, Fig. 6).
The activity of farms in obtaining CAP assistance measures was shown to differ sharply, both in terms of the number of its types (16) and the number of spatial units where those types oc-

Table 7. Types of structural activity of agricultural holdings under CAP assistance measures.

\begin{tabular}{|c|c|c|c|c|c|}
\hline \multirow[b]{2}{*}{ Type (no.) } & \multicolumn{4}{|c|}{ Level of farm activity* } & \multirow[b]{2}{*}{$\begin{array}{l}\text { Number } \\
\text { of poviats }\end{array}$} \\
\hline & $\begin{array}{c}\text { natural } \\
\text { environment }\end{array}$ & $\begin{array}{l}\text { agrarian-demo- } \\
\text { graphic structure }\end{array}$ & $\begin{array}{l}\text { technical } \\
\text { equipment }\end{array}$ & income situation & \\
\hline I & 1 & 1 & 1 & 1 & 60 \\
\hline II & 1 & 1 & 1 & 2 & 22 \\
\hline III & 1 & 1 & 2 & 1 & 2 \\
\hline IV & 1 & 2 & 1 & 1 & 19 \\
\hline $\mathrm{V}$ & 2 & 1 & 1 & 1 & 22 \\
\hline VI & 2 & 2 & 1 & 1 & 17 \\
\hline VII & 1 & 2 & 2 & 1 & 26 \\
\hline VIII & 2 & 1 & 2 & 1 & 10 \\
\hline IX & 2 & 1 & 1 & 2 & 11 \\
\hline$x$ & 1 & 1 & 2 & 2 & 3 \\
\hline XI & 1 & 2 & 1 & 2 & 5 \\
\hline XII & 1 & 2 & 2 & 2 & 15 \\
\hline XIII & 2 & 2 & 2 & 1 & 65 \\
\hline XIV & 2 & 1 & 2 & 2 & 2 \\
\hline$X V$ & 2 & 2 & 1 & 2 & 13 \\
\hline XVI & 2 & 2 & 2 & 2 & 22 \\
\hline
\end{tabular}

*1- below national average; 2 - above national average Source: own compilation. 


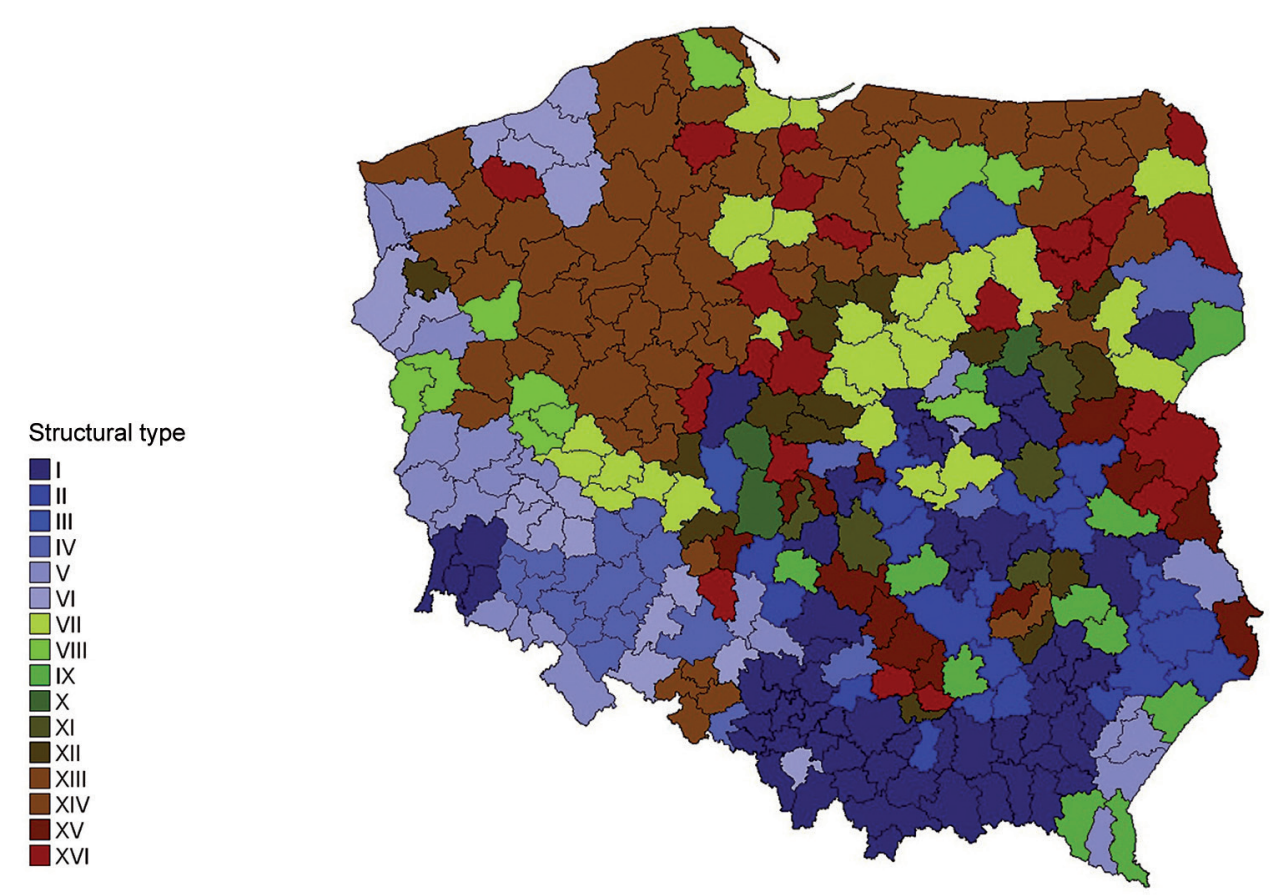

Fig. 6. Types of structural activity of agricultural holdings under CAP assistance measures. Source: own compilation.

curred. The most popular types of absorption structure were I (E-1, A-1, T-1, D1, or low activity in all the groups distinguished: 60 poviats and three voivodeships: Małopolska, Subcarpathia and Silesia) and type XIII (E-2, A-2, T-2, I-1, or low activity only in the group of measures intended to improve the income situation of agricultural holdings: 65 poviats and six voivodeships: Kujavia-Pomerania, Podlasie, Pomerania, Warmia-Mazuria, Wielkopolska and West Pomerania; cf. Tables 6 and 7). The spatial pattern of those types reflects chief differences in the level of Polish agriculture, viz. between the south-east (type I) and the north of the country (type XIII). The other types were represented by a much smaller number of poviats, more strongly differing spatially, and located in several regions (e.g. type II: E-1, A-1, T-1, I-2 - 22 poviats, of which eight in Lublin, four in Łódź, three in Małopolska, one in Mazovia, two in Subcarpathia, one in Silesia, and three in Świętokrzyska Land; or type IX: E-2, A-1, T-1, I-2 - 11 poviats, of which three in Lublin, one in Łódź, one in Mazovia, three in Subcarpathia, one in Podlasie, and two in Świętokrzyska Land). In this group there are also types that include a mere 2-3 units, viz. type III (E-1, A-1, T-2, D1 - two poviats: Kalisz in Wielkopolska and Szczytno in Warmia-Mazuria), type X (E-1, A-1, T-2, I-2 - three poviats: Sieradz in Łódź, Turek in Wielkopolska, and Wyszków in Mazovia), and type XIV (E-2, A-1, T-2, I-2 - two poviats: Kartuzy in Pomerania and Opatów in Świętokrzyska Land; cf. Fig. 6).

To give a more synthetic view of the structure of the CAP assistance measures implemented by agricultural holdings, the most important (leading) element was identified in a given spatial unit, i.e. one assuming the highest normalised value there. In this way four types of area were distinguished where the measures were clearly intended to improve:

- natural conditions (type 1) - four voivodeships: Lubuska Land, Subcarpathia, Pomerania and West Pomerania, as well as 96 poviats, mostly situated in northern and western Poland;

- the agrarian-demographic structure (type 2) - four voivodeships: Lower Silesia, Mazovia, Opole, and Podlasie, as well as 75 poviats, largely forming a territorially compact zone extending from Opole and Lower Silesia, then Kujavia-Pomerania, Łódź, and Mazovia, and finally Podlasie and Warmia-Mazuria;

- technical equipment (type 3) - three voivodeships: Kujavia-Pomerania, Warmia-Mazuria and Wielkopolska, as well as 59 poviats situated within their borders (plus seven poviats from Pomerania); and 


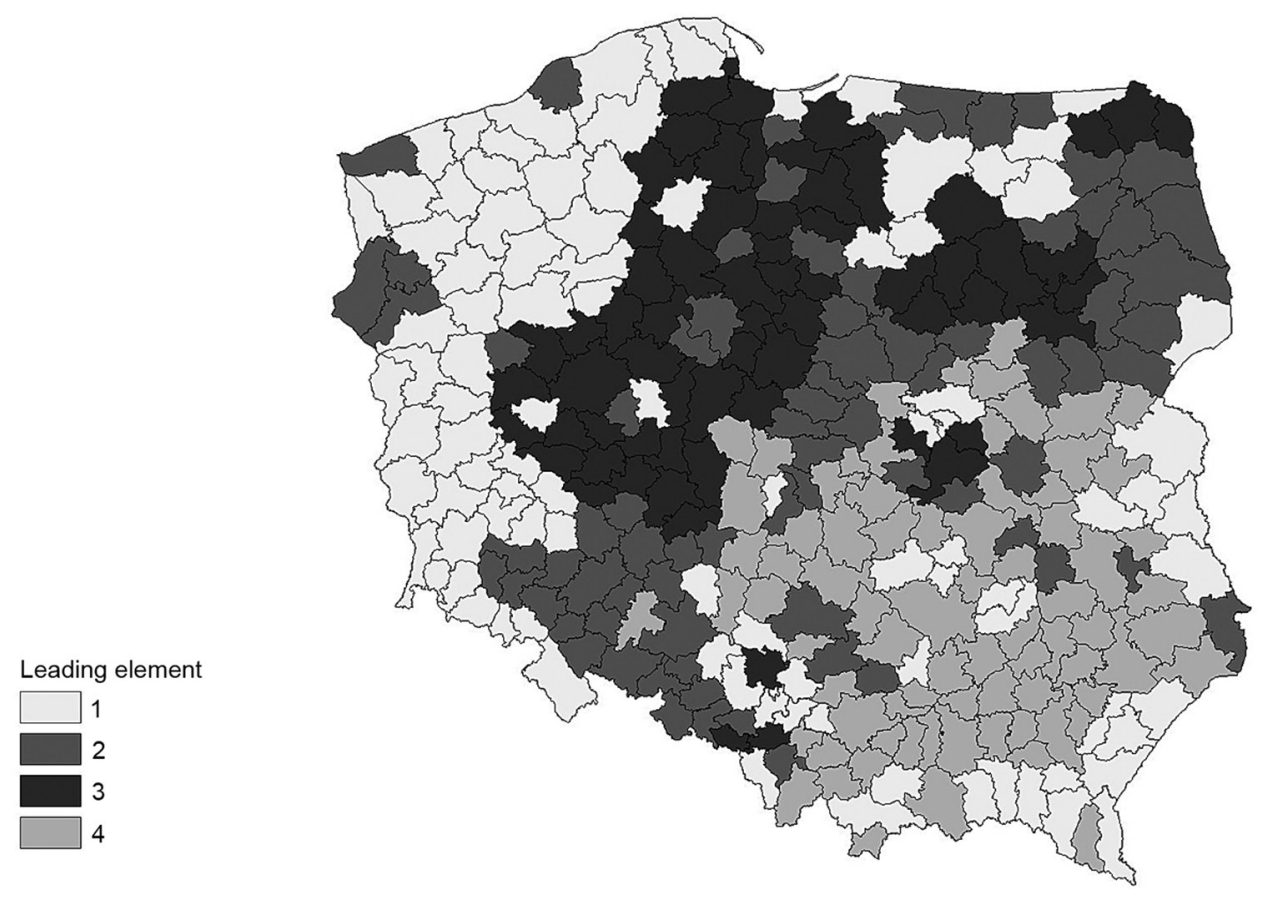

Fig. 7. Agricultural holdings by predominating type of activity in obtaining EU funds.

1 - improvement of natural environment, 2 - improvement of agrarian-demographic structure, 3 - improvement of technical equipment of farms, 4 - improvement of income situation of farming families Source: own compilation on the basis of AR\&MA and GUS data.

- the income situation of agricultural holdings (type 4) - five voivodeships: Lublin, Łódź, Małopolska, Silesia and Świętokrzyska Land, as well as 77 poviats, mostly situated in central and south-eastern Poland (cf. Table 6, Fig. 7).

The analysis showed that while no leading measures intended to improve the natural environment and the agrarian-demographic structure could be found in areas distinguished in terms of natural, historical and urbanisation-related determinants (cf. Table 6), over the years 2002-2010 Polish farms differed in the purpose for which they applied for EU means, which makes it possible to identify areas where their preferences in this respect are clearly visible.

\section{Final remarks}

The conducted analysis demonstrated that over the years 2002-2010 there were wide spatial differences in the activity of agricultural holdings in obtaining EU funds, both by voivodeship and by poviat. This was corroborated by large disproportions in the percentage of applications granted in the total number of farms, both in terms of the individual Common Agricultural Policy meas- ures and their joint treatment (on average, 58.9\%), and when divided into four groups: those intended to improve the natural environment (on average, $31.7 \%$ ), the agrarian-demographic structure of farms (on average, 6.6\%), their technical equipment (on average, 9.4\%), and the income situation of farming families (on average, 6.2\%). It was demonstrated that in terms of those four groups, there emerged a spatially diversified pattern of agricultural holdings increasingly departing from intensive forms of production and indicating a growing importance of measures intended to enhance multifunctional development in rural areas. Still, the Community funds absorbed seem to have contributed little to the levelling out of spatial disproportions in the development of Polish agriculture. This is demonstrated by significant differences in the number of payments granted as per cent of the total number of farms between areas with small farm sizes and a low level of economic performance (historically belonging to the former Austrian sector and interwar Poland) and those with a favourable farm-size structure and a high level of farming practices (historically belonging to the former Prussian sector and interwar Poland), viz. $32.1 \%$ and $84.1 \%$, respectively. The differences are especially great in measures 
intended to improve natural conditions $(20.0 \%$ vs. $44.2 \%)$, the agrarian-demographic structure of farms (2.6\% vs. 9.6\%), and the technical equipment of agriculture $(1.7 \%$ vs. $22.4 \%)$.

What can be considered an advantageous effect of the CAP funds indicating a departure from intensive forms of agricultural production is the fact that measures enjoying the greatest popularity with farmers were those intended to improve the natural environment (mostly the agri-environmental programme). It is important that this process can be observed not only in less favoured areas (on average, $30.8 \%$ of farms), but increasingly also in poviats with average $(33.2 \%)$ and favourable natural conditions (28.3\%; cf. Table 2$)$ where pro-ecological attitudes were hardly visible in agriculture before Poland's accession to the European Union.

\section{Translated by Maria Kawińska}

\section{References}

Bański J., 2007. Geografia rolnictwa Polski (Geography of Polish agriculture). PWE, Warszawa.

Drygas M., Rosner A. (eds), 2008. Polska wieś i rolnictwo w Unii Europejskiej: dylematy i kierunki przemian (Polish countryside and farming in the European Union: Dilemmas and directions of change). Instytut Rozwoju Wsi i Rolnictwa PAN, Warszawa.

Głębocki B., 2007. Rolnictwo (Agriculture). In: Rogacki H. (ed.), Geografia społeczno-ekonomiczna Polski. PWN, Warszawa: 185-271.

Kołodziejczak A., 2006. Agriculture and the countryside in Poland: alternative scenarios of change. Quaestiones Ge- ographicae 25. Wydawnictwo Naukowe UAM, Poznań: 47-52.

Plan Rozwoju Obszarów Wiejskich 2004-2006 (Rural Development Plan 2004-2006), 2004. Ministerstwo Rozwoju Wsi i Rolnictwa, Warszawa.

Program Rozwoju Obszarów Wiejskich na lata 2007-2013 (Rural Development Programme for the years 2007-2013), 2007. Ministerstwo Rolnictwa i Rozwoju Wsi, Warszawa.

Racine J.B., Reymond H., 1977. Analiza ilościowa w geografii (Quantitative analysis in geography). PWN, Warszawa.

Rudnicki R. (ed.), 2008. Przedakcesyjny Program Rozwoju Rolnictwa i Obszarów Wiejskich SAPARD - studium przestrzenne (Special Accession Programme for Agriculture and Rural Development SAPARD: A spatial study). Biuletyn Instytutu Geografii Społeczno-Ekonomicznej i Gospodarki Przestrzennej UAM w Poznaniu, Bogucki Wydawnictwo Naukowe, Poznań.

Rudnicki R., 2009. Renty strukturalne jako czynnik przemian agrarnych $i$ demograficznych $w$ rolnictwie polskim w latach 2004-2006 (Structural pensions as a factor of agrarian and demographic change in Polish farming over the years 2004-2006). Bogucki Wydawnictwo Naukowe, Poznań.

Rudnicki R., 2010. Zróżnicowanie przestrzenne wykorzystania funduszy Unii Europejskiej przez gospodarstwa rolne w Polsce w latach 2004-2006 (Spatial differences in the absorption of the European Union funds by agricultural holdings in Poland over the years 2004-2006). Bogucki Wydawnictwo Naukowe, Poznań.

Sektorowy Program Operacyjny “Restrukturyzacja i modernizacja sektora żywnościowego i rozwój obszarów wiejskich" (Sectoral Operational Programme "Restructuring and Modernisation of the Food Sector and Rural Development"), 2004. Narodowy Plan Rozwoju na lata 2004-2006. Ministerstwo Rolnictwa i Rozwoju Wsi, Warszawa.

Shucksmith M., Thomson J.K., Roberts D., 2005. CAP and the regions: the territorial impact of the Common Agricultural Policy. CAB International, Wallingford.

Trouve A., 2006. European Union: the role of the regions in the implementation and financing of agricultural policies. In: Financing agricultural policies with particular reference to public good provision and multifunctionality: Which level of government? OECD, Paris: 26-52. 